\title{
The impact of Brexit on the UK inwards FDI
}

\section{Mihaela Simionescu}

Institute for Economic Forecasting of the Romanian Academy, Centre for Migration Studies in Prague Business School, Global Labor Organization (GLO), 050711, Bucharest - Romania, Casa Academiei, Calea 13 Septembrie nr.13, sector 5 Habilitated Doctor

open (Caccess cc dol

\section{Article history:}

Received: January 12, 2018

1st Revision: February 16,

2018

Accepted: March 19, 2018

\section{JEL classification:}

C51

C53

F21

\section{DOI:}

10.14254/jems.2018.3-1.1

\begin{abstract}
Considering the impact of Brexit on the foreign direct investment (FDI) in the United Kingdom, contrary to previous studies from economic literature, this research focused on two proxies for FDI: FDI projects with the associated new and safeguarded jobs and FDI inflows as percent of GDP. Moreover, other methods were used to measure the Brexit impact on the FDI: a gravity model approach based on mixed-effects Poisson models and a counterfactual analysis based on differences-todifferences estimators. The main results indicated that the number of FDI projects might decrease after Brexit by $65 \%$ till $90 \%$ in 2019 . A higher increase by $97 \%$ is expected to the number of new and safeguarded jobs. Even if FDI inflows in the UK significantly increased compared to the rest of OECD countries because of the EU membership, Great Britain should follow the model of Norway and Iceland after Brexit in order to avoid significant losses in the FDI inflows.
\end{abstract}

Keywords: Brexit, foreign direct investment, FDI projects, Poisson model, differences-in-differences estimator.

\section{Introduction}

The United Kingdom represents the biggest FDI recipient from the entire Europe, having a stock value of almost $£ 1$ trillion, according to the report UK Trade and Investment (UKTI 2015). Moreover, the UK is the third FDI recipient, being after the US and China. Great Britain encouraged FDI for increasing productivity, output and salaries. There are direct and indirect FDI advantages (being more productive, foreign companies also pay higher wages, new management practices and high technologies brought by foreign companies can be adopted by local firms; competitive pressure brings improvements in performance).

In this paper the main objective is to measure how the Brexit will negatively affect the FDI projects and inflows in the United Kingdom. This is the research question for which an answer will 
be given using two alternative methods that catch two aspects of the issue: mixed-effects Poisson models on panel data and counterfactual analysis based on differences-to-differences estimator. It is more than likely that the FDI will decrease if the UK leaves the EU. This implies also the GDP decrease. Measuring the negative impact of Brexit on the UK's inflows is important not for Great Britain where FDI is an engine of economic growth, but also for the rest of the countries in the world that are partner of the UK in FDI. Dhingra et al. (2016) gave few reasons for which FDI will decrease if UK will leave the EU. Being a country in the Single Market, UK is a good export platform for a lot of multinational firms, because of the non-tariff barriers and lower costs when exporting to the other countries from the EU. Multinational firms are endowed with complex supply chains, having many coordination costs between headquarters and local branches. In case of Brexit, it will be difficult to manage these entities. The next trade arrangements between the UK and the EU are marked by many uncertainties that could decrease FDI.

The previous studies showed that the FDI inflows in the UK increased because of the EU membership. Moreover, decreases in the FDI are expected after the UK exit from the EU. For measuring the percent of decrease in bilateral FDI flows, most of the previous studies employed gravity models on panel data, but only few of these were estimated in the context of Poisson models. Compared to previous researches, this paper brings as a novelty the use of mixed-effects Poisson regression models based on panel data. The past studies focused only on the bilateral flows, most of them showing a decrease in FDI after the Brexit (Campos \& Coricelli, 2015; Dhingra et al., 2016). Contrary to previous studies, we focused on explaining the number of FDI projects and number of new and safeguarded jobs ensured by these FDI in the UK. As almost all of the economists anticipated (Campos \& Coricelli, 2015; Ebell \& Warren, 2016; Driffield \& Karoglou, 2016), the UK's Brexit will put problems to labour market that should become more flexible. This aspect is essential, mostly because the evaluation of the Brexit impact on jobs brought by FDI projects has not been made yet in the economic literature. The results were consistent with the expectations, the issues on labour market being reflected in a lower GDP growth.

The evaluation of Brexit impact on FDI is the support for the next economic policies in the UK. Some policy recommendations should take into account the reduction of the expected deficit of competitiveness in the UK.

The paper is structured as follows. After the introduction, the literature review is described indicating the most relevant studies regarding the impact of Brexit on the FDI in the UK. The next sections make a description of methods, data and results. The last part brings some conclusions.

\section{Literature review}

In the context of the economic integration, four freedoms specific to Internal Market will be affected: free capital movement which includes FDI, free people movement, free services movement and merchandise trade. In this context, Ebell and Warren (2016) showed that EU membership had a positive impact on the UK inward FDI, because of free capital movement and because of free goods and services trade, including labour mobility and passporting that made the UK the most attractive FDI destination country from the entire Europe.

The inward FDI of the UK consistently grew after the entrance in the EU, especially because of the UK's exports to CEE countries without a common external tariff. The introduction of the Single Market Programme in the late 1980s eliminated many internal barriers to investment and cross-border trade. Straathof et al. (2008) showed that EU membership determined an increase in inward FDI stocks by $14 \%$ compared to non-EU countries and by $28 \%$ when the partners are the other EU countries. According to the estimations of Pain and Pickering (1997), the Single Market Programme had a high positive impact on the FDI inflows in the UK. Using the synthetic controls method Campos and Coricelli (2015) estimated a positive impact of the EU membership of the UK on the FDI translated into an increase in the bilateral flows by $25 \%$ till $30 \%$ over $1986-2015$. The same authors used also different econometric models (OLS regression, Heckman and Poisson models) to show that the average increase in bilateral FDI flows is around $28 \%$.

The consequences of more attracted FDI for the UK are related to a higher productivity due to management practices and high technologies (Bloom et al. (2012)) and to FDI spillover for domestic companies (Haskel et al. (2007)). Moreover, Alfaro et al. (2004) proved that FDI inflows are a determinant of economic growth in the UK, mostly because of the financial sector that is well developed in this country. With higher FDI flows due to EU membership, the UK increased its GDP with $2.25 \%$ according to Pain and Young (2004) that used a macromodel for the British economy with endogenous monetary and fiscal policies. All these positive effects of the economic integration might change into negative ones in case of Brexit.

The scope of sovereignty for national regulation might also be influenced by the Brexit. The effects might extend to entire investment and business environment of the UK. Less FDI because of 
Brexit might have many negative consequences, among them being: decrease in production and in employment, less productivity and technical progress because of the less concurrence. The legal framework will also be affected, because for an EU country will be more difficult to establish in the UK after Brexit. Moreover, the laws of protection corresponding to EU countries will not be in the favour of the UK.

In assessing the impact of Brexit on the FDI in the UK, the FDI reasons should be considered. MNCs might use FDI for local production or might export. Their choice affects the location competitiveness, but also costs of trade because of the trade barriers and distance. In case of high barriers for trade, the export is expensive and FDI in foreign market is more attractive. After Brexit, the production relocation from the UK to other locations would be a solution for the EU countries. In case of financial services, the interest might move from London to other cities like Frankfurt, Dublin or Paris. The costs of adjustment for large EU companies in the UK might be considerable. After Brexit, the competition will increase and Great Britain should improve the business environment and the taxation system. In the last years, the UK succeeded in attracting many FDI projects and corresponding jobs. After Brexit, the competitiveness will be negatively affected and one way to restore it is to undercut social regulation and taxation, excepting environmental legislation. The UK may choose to act as Ireland and this will create many risks to EU by the constrains and obligations.

Another reason for FDI might be the international supply chain optimization with production sites in various countries. Higher trade costs and more time for transactions might create problems to the UK firms that can choose other locations from the EU. Moreover, the EU companies could eliminate UK from the international value chains. The UK is most preferred by non-European companies, but after Brexit this function might be eroded depending on the intensity of the new trade barriers. Barret et al. (2015) computed the location probabilities using data regarding the location of newly established foreign affiliates in the EU countries over 2005-2014. For UK, the probability of establishing new foreign affiliates in this country is $12.7 \%$. If the UK market access decreases with $50 \%$, this probability arrives to $2.9 \%$. The investment relocation might be explained also by the decision of some banks to move the operations out of the Great Britain. Nissan and Toyota are large companies that announced in 2016 their relocation decisions.

There are some recent studies that assessed the impact of Brexit on FDI inflows and economic growth in the UK, providing forecasts regarding the FDI or GDP decrease (Mansfield (2014) Campos and Coricelli (2015), Irwin (2015), Barret et al. (2015), Ebell and Warren (2016), Dhingra et al. (2016), Featherstone (2016), Kierzenkowski et al. (2016)). Campos and Coricelli (2015) showed that FDI flows will fall because of Brexit with 12\%, 28\% and 25\% respectively to the model used in making estimation (OLS regression, Heckman model, and Poisson model). Their results are consistent with the PWC (2016) estimation of decrease by $25 \%$ till 2020. Dhingra et al. (2016) used gravity models for 34 OECD countries over 1985-2013 and showed that the UK's bilateral FDI flows will decrease with almost 28\%. Some scenarios were built up by Ebell and Warren (2016) for the next 15 years. The authors predicted a decrease in the UK's FDI by $12 \%$ till $28 \%$ and a GDP rate between $1.5 \%$ and $3.7 \%$ by 2030 . Some authors, like Driffield and Karoglou (2016), avoided to provide an exact numerical evaluation of Brexit's effect on FDI as a reference value. The main argument is the high degree of uncertainty of the unstable and very dynamic international framework. However, Driffield and Karoglou (2016) obtained a negative effect of Brexit on the FDI in the UK using a Markov regime-switching structural vector-autoregression and they provided some recommendations in terms of potential policies in the Great Britain: increase in the labour market flexibility, a more intensive trade with countries for which lower costs are ensured, decrease in the degree of employment protection.

The effects of Brexit on FDI might be studied in correlation with other countries that made high investments in the UK. For example, less FDI from Ireland to the UK will negatively influence the economic growth in Ireland, according to Barrett et al. (2015) estimations. Moreover, Ireland could attract lower FDI projects from the UK after Brexit. The financial sector in Ireland might take advantage as Purdue and Huang (2015) concluded, but the energy market on which UK's investors have an important role will be negatively affected. The FDI flows from Switzerland to UK might diminish by $17.1 \%$ and those from Norway to UK by $9.7 \%$ according to the estimations of Ebell and Warren (2016). Similar results were obtained in the Treasury analysis (a decrease by $10 \%$ of UK's FDI in Norway and by 15\%-20\% in Switzerland).

Even if all of these studies estimated a large and negative impact of Brexit on the UK's FDI, the Open Europe model mitigates this effect. However, the Open Europe model expectations are not plausible, according to Harvey and Hubbard (2016) who showed that the Open Europe model uses a fixed exchange rate, when, actually, adjustment re expected to capital inflows and exchange rates. On the other hand, the model did not include the short-term transitional costs. 


\section{Methodology}

\subsection{Gravity approach based on Mixed-effects Poison regression models}

The gravity model is based on Newton's Law of Gravity. This law considers that the gravitational attraction between objects is directly proportional with their masses and inversely proportional with the distance. The gravity models were firstly applied in Economics to estimate the trade flows $T F_{i j}$ from a country $i$ to another country $j$. The countries' GDPs are considered as a measure of the economic mass.

$$
T F_{i j}=C \frac{G D P_{i}^{\alpha} G D P_{j}^{\beta}}{D_{i j}^{\gamma}}
$$

$T F_{i j}$ - trade flows between countries $i$ and $j$

$D_{i j}$ - distance between countries $i$ and $j$

The logarithm is applied to the equation (1), resulting:

$$
\ln T F_{i j}=\ln C+\alpha \ln G D P_{i}+\beta \ln G D P_{j}-\gamma \ln D_{i j}
$$

$\alpha, \beta$ and $\gamma$ - elasticities.

Other applications in Economics for gravity models fare related to bilateral FDI flows and migration flows, both of them being influenced by the geographical location.

Compared to previous approaches in the economic literature, the novelty of this paper is given by the fact that the gravity approach is brought in the context of mixed-effects Poisson regression models. The dependent variable is not represented by bilateral FDI flows or FDI inflows, as in Campos and Coricelli (2015). The dependent variable shows the number of events (number of FDI projects or number of jobs).

The mixed-effects Poison regression model shows the expected number of counts in a period of time during some events are registered $\left(t_{i j}\right)$ :

where

$$
E\left(y_{i j}\right)=\mu_{i j}=t_{i j} \exp \left[x_{i j}^{I} \beta+z_{i j}^{r} \vartheta_{i}\right]
$$

$\mathrm{i}=1,2, \ldots, \mathrm{N}$ level- 2 units (for clusters)

$\mathrm{j}=1,2, \ldots, n_{i}$ level- 1 units (for multiple observations)

$y_{i j}$ - dependent variable (number of events) variable)

$t_{i j}$ - period of time during which these events are registered (sometimes known as offset

$t_{i j}=t$, if all observations are related to the same time period when the number of events is of interest

$t_{i j}$ varies when the observations are related to varying periods; this aspect is relevant in modeling process.

$x_{i j}$ - covariates at first, second level or cross-level interactions; it may include dummy variables, polynomials, interactions etc.

$\beta$ - parameters of regression for covariates

$z_{i j}$ - random effect variable/variables which might be, in most cases, an intercept for clustered data or time and intercept for longitudinal data matrix $\Sigma_{\vartheta}$

$\vartheta_{i}$ - random effects following a normal distribution of null mean and variance-covariance

It shows how cluster $i$ influences the observations within the cluster and how an individual/cross-section starts and makes progress in time. 


$$
\begin{gathered}
\log \left(\mu_{i j}\right)=\log \left(t_{i j}\right)\left[x_{i j}^{\prime} \beta+z_{i j}^{\prime} \vartheta_{i}\right] \\
\log \left(\mu_{i j}\right)-\log \left(t_{i j}\right)=x_{i j}^{\prime} \beta+z_{i j}^{r} \vartheta_{i} \\
\log \left(\mu_{i j} / t_{i j}\right)=x_{i j}^{\prime} \beta+z_{i j}^{r} \vartheta_{i}
\end{gathered}
$$

The log link is the link function for the Poisson regression. The event rate ratio or the incidence is represented by $\exp \beta$.

The mixed-effects Poison regression model that does not include an offset variable has the following form:

$$
\log \left(\mu_{i j}\right)=x_{i j}^{r} \beta+z_{i j}^{r} \vartheta_{i}
$$

If the offset variable is included, then:

$$
\log \left(\mu_{i j}\right)=\log \left(t_{i j}\right)+x_{i j}^{I} \beta+z_{i j}^{r} \vartheta_{i}
$$

The logarithm of the offset variable is like an explanatory variable with slope equaled to 1 . In Poisson models, the assumption is that mean and variance are equals. The overdispersion might appear when the variance is larger than the average. This overdispersion, which is present in many cases in real data, generates estimates distortion. The possibility of overdispersion can diminish by including random effects and taking into account the individual differences. In the case of Negative Binomial model, an overdispersion parameter is included for relaxing this hypothesis. Actually, the Poisson model is a particular case of the Negative Binomial Model under the assumption that the overdispersion parameter is null.

Gibbons et al. (2008) considered three approaches for estimating a Poisson regression: semiparametric or parametric fully Bayes estimation (FB) and empirical Bayes (EB) estimation. The differences between these approaches are related to way of specifying and estimating the distribution of random coefficients vector. In the case of parametric FB and EB, the distribution is normal. The distribution's parameters for EB method are inferred by point estimation, the maximum marginal likelihood being used. The inference is based on posterior distribution in the case of FB method. In the case of semi-parametric FB estimation, a non-parametric prior is associated to distribution of random effects. The main disadvantage of EB approach is the assumption that random effect of covariance matrix is considered to be known. This limit is eliminated by FB approaches that include a prior distribution for the parameters associated to random effects distribution. Parametric FB method was used by El-Sayyad (1973) to provide inferences for mixed-effects Poisson models, an improper prior being selected. The author considered the fact that for large shape parameter the repartition of gamma variable logarithm might by approximated by the normal repartition. Under this hypothesis, the posterior density has a multivariate normal repartition. The semi-parametric FB is more flexible, because Dirichelet process stands for the entire space of distributions associated to random effects. All normal repartitions are included.

In this paper, the dependent variable is represented by turn by the following variables: number of FDI projects, number of new jobs created by the FDI projects and number of safeguarded jobs due to the FDI projects. These variables refer to the projects and jobs brought by main foreign investors in the UK around the entire world (France, Germany, Italy, Spain, Ireland, Switzerland, Canada, US, rest of Americas, Australia, India, China, Japan, rest of Asian-Pacific states). The time period refers to 2012-2015. The source of data is the UKTI Inward Investment Report for this period.

\subsection{Differences-in-differences approach}

Another approach for measuring the impact of the EU membership on the UK's FDI is related to the counterfactual analysis. This approach was also applied by Campos and Corricelli (2015) using Synthetic Control Method for a model based on trade openness, GDP per capita and size of the market. In the period from 1986 to 2014, the UK received between 25\% and 30\% more FDI, because it was an EU member. However, the authors considered that their results should be cautiously taken into consideration, because they may vary over time. A more realistic approach would be the comparison of the UK with other countries that did not enter the EU. In this context, contrary to previous studies regarding the Brexit effect on FDI (Campos \& Corricelli (2015), Ebell \& Warren (2016), Driffield \& Karoglou (2016), Simionescu (2016)) we employed the differences-indifferences estimator to measure the impact of the EU membership on FDI in the case of the UK. Differences-in-Differences (DD) estimation became a common way to estimate causal relationships. 
It supposes the identification of a specific treatment or intervention. The differences in outcomes (in our case, in FDI inflows) are compared before and after the intervention for groups (countries) that supported the intervention to the same difference for groups that were not affected by that intervention. In this particular case, we consider that the UK suffered an intervention (the entrance in the EU) which affects FDI. We compare the changes in FDI inflows in the UK or some EU countries including the UK with the changes in the FDI of the countries that did not enter the EU. The DD approach is simple and it surpasses many problems related to endogenity generated by comparisons made between heterogenous cross-sections as Meyer (1995) explained. This method is suitable for random interventions that are conditioned by fixed effects and time. The intervention's endogenity makes the results invalid. In most cases, DD estimators and the corresponding standard errors are based on Ordinary Least Squares using cross-section or panel data. In our case, we have countries in treatment (intervention) and control groups for some years before and after the UK entrance in the EU which was in 1970. Let us consider $Y_{i s t}$ the outcome for country I in the group s (state s) by time t. A dummy variable $I_{s t}$ is considered in order to mark if the intervention (entrance in the EU) affected that group at a certain time.

$$
Y_{i s t}=A_{s}+B_{t}+c X_{i s t}+\beta I_{s t}+e_{i s t}
$$

$$
\begin{aligned}
& A_{s}, B_{t} \text { - states' fixed effects } \\
& X_{\text {ist }} \text { - individual control } \\
& e_{i s t} \text { - error }
\end{aligned}
$$

The intervention impact is measured by the estimate of $\beta$. The confidence intervals are built for this parameter using the OLS standard error, which in some cases are corrected with the shocks' correlation in each state and each year. The above specification is the general case of the DD framework with 2 groups and 2 periods. The results are valid only under the assumption that modifications in the dependent variable over time would have been the same in both groups when the intervention lacks.

According to Greene (2002), in case of errors' serial correlation, the t-statistics and significance levels are overestimated. The causes might be multiple, but different procedures are used to correct this problem.

\section{Variables and data}

The aim is to analyze the UK inward FDI projects and associated jobs by origin country, focusing on GDP per capita and the distance as factors of influence. In this context, the gravity model is the best choice. The FDI projects and jobs were initiated in the UK by foreign countries and regions: France, Germany, Italy, Spain, Ireland, Switzerland, Canada, US, rest of Americas, Australia, India, China, Japan, rest of Asian-Pacific states during 2012-2015. A description of the variables in the study is realized in the following table.

The FDI inflows as percent of GDP (\%) were consider as variable in the counterfactual analysis. Foreign direct investment represents the net inflows of investment to obtain a long-term management interest (at least $10 \%$ of voting stock) in a company that operates in another economy than the investor's one. The indicator is computed as the sum of equity capital, earnings' reinvestment, other long-run capital, and short-term capital in the balance of payments. The data series indicated net inflows (new investment inflows minus disinvestment) in the reporting country from foreign investors, being divided by GDP.

According to correlation matrix, import and export are two strongly correlated variables. So, one of these variables will be dropped (import will be dropped).

A global analysis of number of FDI inward projects and associated jobs is also necessary, the data being provided by Ernst and Young attractiveness surveys. The number of FDI projects in the UK had reached the maximum level in 2015, after periods of increases and decreases. Before 2008, when the global economic and financial crisis started, the number of FDI projects increased from a year to another. In 2008 and 2009 a sudden drop was observed in the context of the economic crisis when the foreign investors became more cautious. A slow recovery was observed in 2010 (an increase with around $17 \%$ compared to 2009), but in 2011, the number of FDI projects in the UK decreased again with almost $6.8 \%$ with respect to 2010 . The managers tried to protect the bottom line, being sapped by low consumer confidence, high global uncertainty and by the austerity measures taken by government. Since 2012, the FDI inward projects registered a fast growth from a 
year to another till the maximum level in 2015. However, the result of Brexit might seriously affect the number of projects in the next years.

\begin{tabular}{|c|c|c|}
\hline Variable & Description & Data source \\
\hline $\begin{array}{l}\text { number of FDI } \\
\text { projects }\end{array}$ & $\begin{array}{l}\text { Number of FDI projects of the mentioned regions in } \\
\text { the UK }\end{array}$ & $\begin{array}{l}\text { UKTI Inward Investment Report } \\
\text { from 2012/2013, 2013/2014 } \\
\text { and } 2014 / 2015\end{array}$ \\
\hline $\begin{array}{l}\text { number of new } \\
\text { jobs }\end{array}$ & $\begin{array}{l}\text { number of new jobs created by the mentioned } \\
\text { regions in the UK through the FDI projects }\end{array}$ & $\begin{array}{l}\text { UKTI Inward Investment Report } \\
\text { from 2012/2013, 2013/2014 } \\
\text { and 2014/2015 }\end{array}$ \\
\hline $\begin{array}{l}\text { number of } \\
\text { safeguarded jobs } \\
\text { from FDI projects }\end{array}$ & $\begin{array}{l}\text { number of safeguarded jobs in the UK due to the FDI } \\
\text { projects of the mentioned regions }\end{array}$ & $\begin{array}{l}\text { UKTI Inward Investment Report } \\
\text { from 2012/2013, 2013/2014 } \\
\text { and } 2014 / 2015\end{array}$ \\
\hline GDP/cap & $\begin{array}{l}\text { GDP per capita (in PPP in constant } 2011 \\
\text { international \$): Gross Domestic Product over the } \\
\text { total population }\end{array}$ & World Bank database \\
\hline $\begin{array}{l}\text { manufacturing } \\
\text { value added }\end{array}$ & $\%$ of GDP & World Bank database \\
\hline $\begin{array}{l}\text { total } \\
\text { unemployment } \\
\text { rate }\end{array}$ & Number of unemployed people over total labor force & World Bank database \\
\hline $\begin{array}{l}\text { exports of goods } \\
\text { and services }\end{array}$ & $\%$ of GDP & World Bank database \\
\hline $\begin{array}{l}\text { imports of goods } \\
\text { and services }\end{array}$ & $\%$ of GDP & World Bank database \\
\hline DISTANCE & $\begin{array}{l}\text { The distance between London and the capital of } \\
\text { each country or the capital of the country with } \\
\text { highest FDI to the UK in the region (kilometers) } \\
\text { (flying distance). For the rest of America we took the } \\
\text { capital of Virgin Islands and for rest of APAC we took } \\
\text { capital of Malaysia. }\end{array}$ & http://www.distancefromto.net/ \\
\hline common_language & $\begin{array}{l}\text { Dummy variable, which takes } 1 \text { for English language } \\
\text { (in US, Canada, rest of America where some islands } \\
\text { are British territories) and } 0 \text { for the rest of the } \\
\text { languages in the other countries }\end{array}$ & \\
\hline EU_member & The country is member of the European Union & \\
\hline
\end{tabular}

Source: author's construction

Figure 1: The evolution of the number of FDI inward projects in the UK over 2005-2015

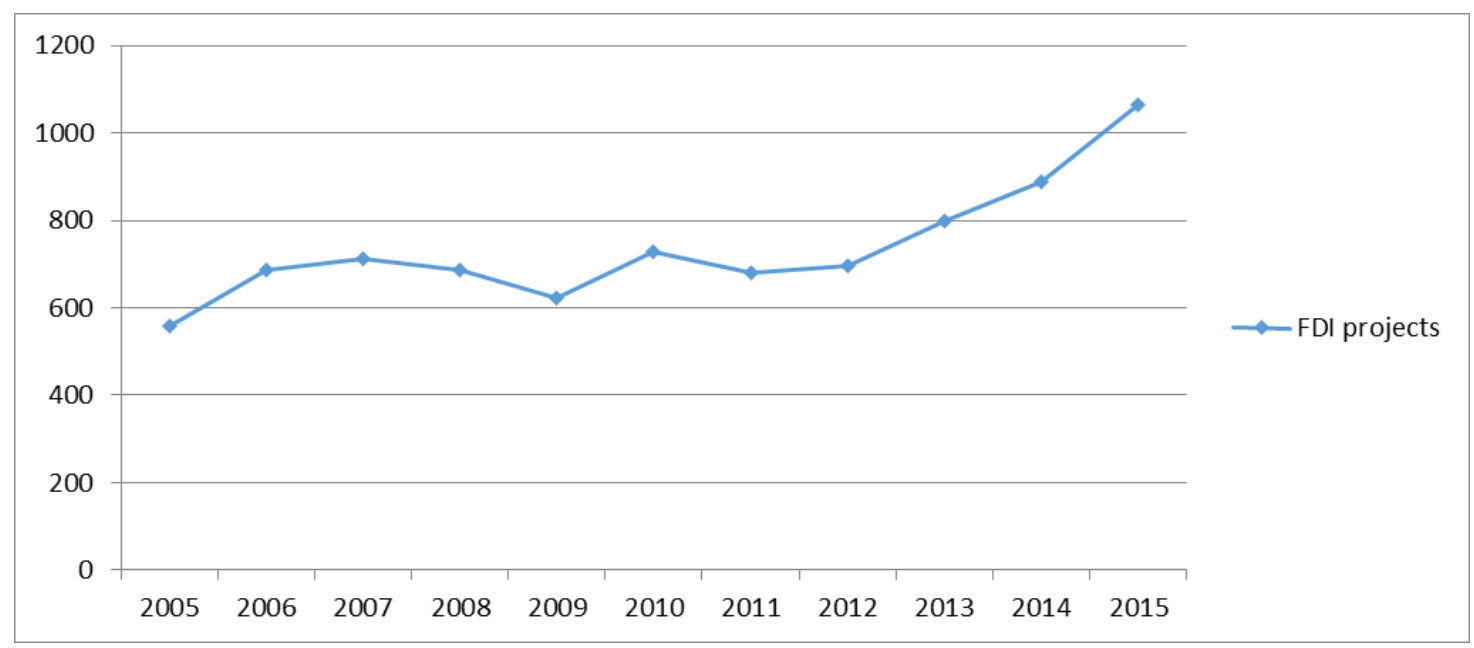

Source: author's graph 
Figure 2: The evolution of the number of new jobs from FDI inward projects in the UK over 2005-2015

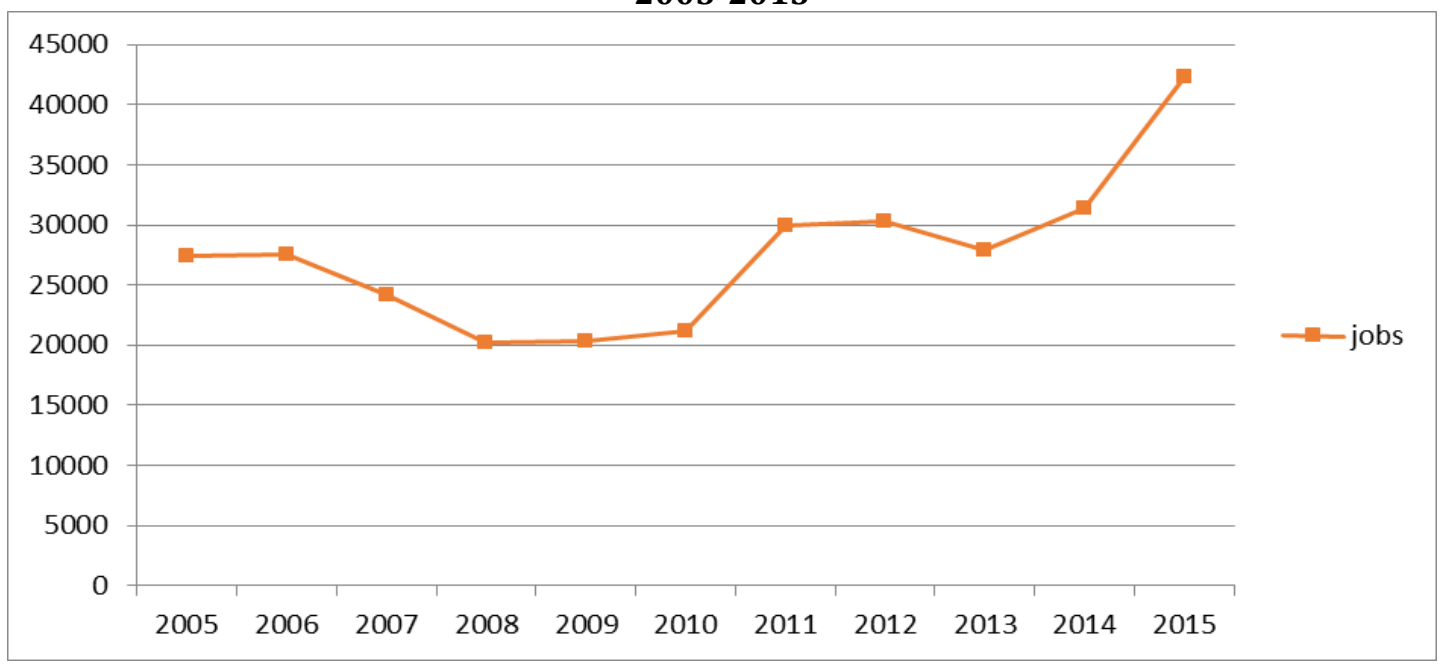

Source: author's graph

The number of new FDI jobs began to decrease since 2007 with a slow recovery during 2009-2012. However, in 2013, the number of new jobs decreased suddenly with almost $7.8 \%$ compared to 2012. The growth trend was revived till a maximum level in 2015. The low performance in 2013 might be explained by the fact that the entire Europe faced a difficult phase of economic crisis and the recovery in the UK started in the last quarter of 2013. Moreover, the contribution of manufacturing to the GDP continued to decline. In 2013 and 2014, Germany was considered the most attractive FDI destination in the Europe, while the UK was on the second place. In 2015, the UK imposed the supremacy, but the uncertainty generated by Brexit will put problems to the UK in terms of FDI. It is more likely for Germany to become the most attractive FDI destination, being also helped by the political context.

In 2015, the UK was the country with the largest number of FDI projects and of new corresponding jobs within Europe. Even if the world FDI flows decreased in 2014-2015 with 11\%, the UK number of FDI projects increased by 1.5 times in 2014-2015 compared to the previous period. Only three countries (the UK, France and Germany) accounted more than half (51\%) of the FDI projects across the entire Europe in 2015. Regarding investor sentiment, London is the most attractive destination from Europe, being followed by Paris. The UK was the first destination in Europe for FDI projects regarding hospitality and retail, while Germany performed better than Great Britain in terms of projects for communication and transport. It is more than likely that the Brexit will affect the UK's projects in hospitality and retail, unless suitable policy measures would not be implemented.

Some economists, like Irwin (2015), consider that Ireland will be one of the most exposed states to Brexit effects, because it shares strong investment. Moreover, McGrath (2016) predicted that Ireland's GDP rate will diminish after Brexit. The reasons of high impact of Brexit on Ireland's economy are multiple: proximity and the alignment of Ireland to the UK's requirements regarding regulatory and trade policy objectives. In contrast, France will be among the countries with the lowest risk of exposure. The political and economic contagion determined by Brexit might negatively affect Italy. After the UK exit, Germany might be winner in many policy debates. Spain also will be affected in a negative way, because it still tries to recover after economic crisis. In our opinion, the concept of leaving the EU will be the biggest threat for the EU which might go to till disintegration.

\section{Results}

The empirical analysis based on gravity model uses mixed-effects Poisson regression models. In previous studies, like those of Campos and Coricelli (2015) and Bruno et al. (2016), only Poisson models without any effects were considered. Our approach based on mixed-effects is a novelty for economic field, the method being specific to data from medicine, imagine processing, geostatistics. The existence of location specific variation connected with between location correlation justify the use of mixed effects Poisson regressions for studying spatial count data. Beside this approach, we also employed the DD estimator that has not been used before in literature in the context of Brexit impact analysis. 
More mixed-effects Poisson regressions were estimated. We consider that the quality of EU member depends on the distance between UK and the country. We took into account that the UK is closer to European countries in the EU than other partner countries from America or Asia.

For explaining the number of FDI projects in the UK, three mixed-effects Poisson model were estimated. The reference country is only the UK and a simplified form of the gravity model is used. The common aspect regarding all these models is the fact that EU membership had a positive impact on FDI project and the distance was not relevant. In other words, the EU countries were more motivated to invest in the UK, another EU country. However, the distance was not a barrier for foreign investors in the UK. The EU countries did not invest more in the UK because it was closer. Other reasons like the EU membership explained more the FDI projects attraction in the UK.

Firstly, we consider the simple case of a gravity model when the FDI projects is explained using the logarithm of distance and GDP per capita and the dummy variable reflecting the EU membership.

\begin{tabular}{|c|c|c|c|}
\hline Variable & Coefficient & z-calculated & $\mathbf{P}>|\mathbf{z}|$ \\
\hline EU_member & 2.3306 & 8.29 & 0.000 \\
\hline ln(GDP per capita) & 0.6225 & 23.19 & 0.000 \\
\hline $\ln ($ distance $)$ & 0.2018 & 1.47 & 0.141 \\
\hline Constant & -4.6379 & -13.83 & 0.000 \\
\hline
\end{tabular}

Random effects parameter

$\begin{array}{cc}\text { EU_member: independent } & \text { Estimate } \\ \operatorname{sd}(\ln (\text { distance })) & 0.1925 \\ \operatorname{sd}(\text { constant }) & 3.78 \cdot 10^{-7}\end{array}$

Prob. $>$ chi-square $=0.000$

Source: author's calculations

According to the first mixed-effects Poisson model ((M1), the EU membership had a positive impact of the FDI projects in the period 2012-2015. The GDP per capita of the foreign investor had also a positive influence on the FDI projects in the UK. The influence of distance is not relevant between UK and its foreign partners. However, the distance is relevant for the EU countries. The developed countries in the EU are closer to the UK compared to CEE less developed countries. Therefore, the developed countries like Ireland, Germany of France have the advantage of being quite closer to the UK. Joining the EU increased the FDI projects in the UK by 9.28 times. If the UK will leave the EU, the FDI projects might decrease dramatically by $90.27 \%$ in 2019 .

Table 3: Mixed-effects Poisson model (M2) for explaining the number of FDI projects in the UK (2012-2015)

\begin{tabular}{lccc}
\multicolumn{1}{c}{ Variable } & Coefficient & z-calculated & $\mathbf{P}>|\mathbf{z}|$ \\
\hline common_language & 0.6775 & 18.71 & 0.000 \\
EU_member & 2.0341 & 7.30 & 0.000 \\
ln(GDP per capita) & 0.5784 & 22.63 & 0.000 \\
ln(distance) & 0.0546 & 0.45 & 0.652 \\
Constant & -3.0799 & -9.34 & 0.000 \\
Random effects parameter & & & \\
EU_member: independent & Estimate & & \\
sd(ln(distance)) & 0.16933 & & \\
sd(constant) & $3.86 \cdot 10^{-7}$ & & \\
\hline
\end{tabular}

Prob. $>$ chi-square $=0.000$

Source: author's calculations 
Countries that have English as official language were encouraged more than the other countries to invest in the UK, the common language being a relevant determinant of the FDI projects in the Great Britain. In the case of this model, joining the EU increased the FDI projects in the UK by 6.65 times. If the UK will leave the EU, the FDI projects might decrease by $85.92 \%$ in 2019.

Table 4: Mixed-effects Poisson model (M3) for explaining the number of FDI projects in the UK (2012-2015)

\begin{tabular}{lccc}
\multicolumn{1}{c}{ Variable } & Coefficient & z-calculated & $\mathbf{P}>|\mathbf{z}|$ \\
\hline common_language & 0.7113 & 12.96 & 0.000 \\
Ln(export) & -0.8983 & -19.82 & 0.000 \\
Ln(manufacturing) & 0.1437 & 2.09 & 0.037 \\
Ln(unemployment) & -0.6191 & -9.03 & 0.000 \\
EU_member & 1.052 & 2.78 & 0.005 \\
ln(GDP per capita) & 0.5299 & 16.76 & 0.000 \\
ln(distance) & 0.0199 & 0.53 & 0.595 \\
Constant & 2.0679 & 3.84 & 0.000 \\
Random effects parameter & & & \\
EU_member: independent & Estimate & & \\
sd(ln(distance)) & 0.0432 & & \\
sd(constant) & $5.44 \cdot 10^{-11}$ & & \\
\hline
\end{tabular}

Prob. $>$ chi-square $=0.000$

Source: author's calculations

It seems that the export and the unemployment rate in the foreign partner country had a negative impact on the FDI projects in the UK. The contribution of the manufacturing sector to the GDP of that country positively affected the FDI in the UK. Countries with large unemployment rates, like Spain, are less encouraged to invest abroad. In the case of this model, joining the EU increased the FDI projects in the UK by 1.86 times. If the UK will leave the EU, the FDI projects might decrease by $65.07 \%$ in 2019 . This last result seems to be more plausible than the other ones. Taken into account that the UK will continue to remain few years in the EU before Brexit, it could take measures to reduce the expected decrease in the FDI.

Table 5: Mixed-effects Poisson model for explaining the number of new jobs of the FDI projects in the UK (2012-2015)

\begin{tabular}{lccc}
\multicolumn{1}{c}{ Variable } & Coefficient & z-calculated & $\mathbf{P}>|\mathbf{z}|$ \\
\hline common_language & 0.4136 & 54.48 & 0.000 \\
Ln(export) & -0.9018 & -116.16 & 0.000 \\
Ln(manufacturing) & 0.0491 & 5.14 & 0.000 \\
Ln(unemployment) & -0.8131 & -82.34 & 0.000 \\
EU_member & 3.6248 & 79.49 & 0.000 \\
ln(GDP per capita) & 0.5299 & 16.76 & 0.000 \\
ln(distance) & 0.2725 & 57.94 & 0.524 \\
Constant & 7.4512 & 98.00 & 0.000 \\
Random effects parameter & & & \\
EU_member: independent & Estimate & & \\
sd(ln(distance)) & 0.1869 & & \\
sd(constant) & $2.26 \cdot 10^{-7}$ & & \\
\hline
\end{tabular}

Prob. $>$ chi-square $=0.000$

Source: author's calculations 
As expected, the countries with high unemployment rates are less encouraged to invest in the UK and to create new jobs here. The high contribution of manufacturing sector to the economic growth of the foreign partner has a positive influence on the creation of new jobs in the UK. Joining the EU increased the FDI new jobs in the UK by 36.51 times. If the UK will leave the EU, the FDI projects might decrease by $97.33 \%$ in 2019 . The effect of Brexit on the new jobs is greater than the impact on the number FDI projects, because the countries in the EU that are also closer to the UK than countries from the other continents are more open to create more jobs. Some of these jobs might be addressed to citizens of the foreign European country that are more eager to go in a country from the same continent.

Table 6: Mixed-effects Poisson model for explaining the number safeguarded jobs of the FDI projects in the UK (2012-2015)

\begin{tabular}{lccc}
\multicolumn{1}{c}{ Variable } & Coefficient & z-calculated & P>|z| \\
\hline EU_member & 3.8794 & 99.60 & 0.000 \\
ln(GDP per capita) & 0.9707 & 180.21 & 0.000 \\
ln(distance) & 0.0983 & 0.53 & 0.598 \\
Constant & -4.5261 & -69.09 & 0.000 \\
Random effects parameter & & & \\
EU_member: independent & Estimate & & \\
sd(ln(distance)) & 0.2620 & & \\
sd(constant) & $4.36 \cdot 10^{-7}$ & & \\
\hline
\end{tabular}

Prob. $>$ chi-square $=0.000$

Source: author's calculations

The economic development of the foreign country has a positive impact on the FDI safeguarded jobs in the FDI projects of the UK. Joining the EU increased the FDI safeguarded jobs in the UK by 47.39 times. If the UK will leave the EU, the FDI safeguarded jobs might decrease by $97.93 \%$ in 2019.

In the context of counterfactual analysis, we start from the following regression model:

$$
Y_{i t}=\alpha+\beta_{1} \text { intervention }_{i t}+\beta_{2} \text { time }_{i t}+\beta_{3} \text { intervention }_{i t} \text { time }_{i t}+\varepsilon_{i t}
$$

Y- dependent variable

time, intervention- explanatory dummy variables

time equals 1 for years after intervention (the UK entrance in the EU)

intervention equals 1 for the EU member

$\mathrm{i}, \mathrm{t}$ - indexes for cross-sections and year

More cases are considered in the analysis:

a) The comparison between the UK and the rest of OECD countries that are not members of the EU;

b) The comparison between the UK and other European countries that are not EU members (Norway, Iceland);

c) The comparison between the EU members from OECD and the non-EU members from OECD.

The data series covers the period from 1970-2014. The UK entered the EU in 1973.

a) First of all, we consider two gropus of countries: the UK and the OECD countries that are not in the EU (Canada, Mexic, Chile, Australia, US, Turkey, New Zealand, Japan, Israel, Norway, Iceland, Korea).

Taking into account that the EU entered the EU in 1973, the time variable will take the value 0 before 1973 and the value 1 for 1973 and after. The difference between the UK and the rest of the 
OECD countries that are not EU members regarding the weight of FDI in GDP (\%) before the UK entered the EU is not statistically significant.

\begin{tabular}{|c|c|c|c|}
\hline Variable & Coefficient & t-stat & $P>|t|$ \\
\hline time & 0.7179 & 3.68 & 0.000 \\
\hline Intervention & -0.0189 & 0.928 & 0.928 \\
\hline time $\mathrm{x}$ intervention & 0.9239 & 2.11 & 0.036 \\
\hline Constant & 1.0356 & 0.000 & 0.000 \\
\hline
\end{tabular}

Note: Prob. $>\mathrm{F}=0.000$

Source: author's calculations

The difference in terms of FDI net inflows between the UK and the rest of the OECD countries that are not in the EU is not statistically significant. If the UK would had not entered the EU, the FDI inflows would have risen with only 0.7 percentage points in the period 1970-2014. The expected change in FDI average before the UK entrance in the EU was different between the two groups of countries. After the UK entrance in the EU, the average difference between Great Britain and the rest of the OECD that are not in the EU was about 0.9 percentage points. This means that the UK attracted more FDI net inflows with 0.9 percentage points of GDP just because it had entered the EU. So, in time the EU membership of the UK was significant, but the percentage of increase in the FDI was not so high.

b) We consider the case with two groups of countries given by UK, on the one hand, and Norway and Iceland, on the other hand.

\begin{tabular}{lccc} 
Table 8: The impact of EU entrance in the EU in terms of FDI compared to Norway and Iceland \\
\multicolumn{1}{c}{ Variable } & Coefficient & t-stat & $\mathbf{P}>|\mathbf{t}|$ \\
\hline time & 1.4136 & 3.76 & 0.000 \\
Intervention & 0.6433 & 3.91 & 0.000 \\
time x intervention & 0.2282 & 0.42 & 0.677 \\
Constant & 0.3733 & 3.61 & 0.000 \\
\hline
\end{tabular}

Note: Prob.>F=0.000

Source: author's calculations

If the UK would had not entered the EU, the FDI net inflows as percent of GDP would have risen with about 1.4 percentage points in the period 1970-2014 compared to Norway and Iceland. The expected change in the FDI average before the UK entrance in the EU was different between the two groups of countries. After the UK entrance in the EU, the average difference between Great Britain and the group formed by Iceland and Norway was about 0.64 percentage points. However, the UK did not attract significantly more FDI net inflows than Iceland and Norway after its entrance in the EU. This conclusion is very important for the UK future policy in terms of FDI after the Brexit. The Great Britain should follow the model of Norway and Iceland. The success of Nordic countries in attracting FDI is due to several strengths as Benito and Grünfeld (2011) noticed: stable political climate, friendly business environment and a persistent economic growth. Some strong points of Iceland in terms of FDI are: flexible labour market, modern infrastructure, strong export industry, a well qualified labour force. The Iceland's government took some measures to encourage FDI attraction: a good company taxation system and simplified formation procedure for firms, freetrade zones and the creation of competitive clusters. Norway also has many strong points like: stable political and business environment, modern infrastructures, well skilled labour force. The government encouraged the FDI attraction by low tax incentives for Norway's foreign and domestic investors, lower tax rates. Norway signed some bilateral treats with some countries. Taken into account these strengths of Norway and Iceland, the UK should focus more on the creation of a flexible labour market and of a modern infrastructure. In the UK, the excessive influence of financial sector on the output should be reduced. Other bilateral treats with the rest of the EU countries are also welcome. 
Table 9: The impact of EU entrance in the EU in terms of FDI compared to Norway

\begin{tabular}{lccc}
$\quad$ Variable & Coefficient & t-stat & P>|t| \\
\hline time & 1.0992 & 4.11 & 0.000 \\
Intervention & 0.4033 & 2.92 & 0.004 \\
time x intervention & 0.5426 & 1.13 & 0.263 \\
Constant & 0.6133 & 12.39 & 0.000 \\
\hline
\end{tabular}

Note: Prob. $>\mathrm{F}=0.000$

Source: author's calculations

If the UK would had not entered the EU, the FDI net inflows as percent of GDP would have risen with about 1.1 percentage points in the period 1970-2014 compared to Norway. The expected change in the FDI average before the UK entrance in the EU was different between the two countries. After the UK entrance in the EU, the average difference between Great Britain and Norway was about 0.4 percentage points. However, the UK did not attract significantly more FDI net inflows than Norway after its entrance in the EU.

c) The impact of the EU integration of the OECD countries after 1973 is assessed. We consider the sample of all the OECD countries, some of them being EU members and some of them not.

Table 10: The impact of some OECD countries entrance in the EU in terms of FDI with respect to the rest of the OECD countries

\begin{tabular}{lccc}
\multicolumn{1}{c}{ Variable } & Coefficient & $\mathbf{t}$-stat & $\mathbf{P}>\mathbf{| t |}$ \\
\hline time & 1.0716 & 7.93 & 0.000 \\
intervention & 0.0605 & 0.37 & 0.712 \\
time $x$ intervention & 2.6454 & 5.13 & 0.000 \\
constant & 0.7565 & 7.58 & 0.000 \\
\hline
\end{tabular}

Note: Prob. $>\mathrm{F}=0.000$

Source: author's calculations

If the UK and the rest of the countries would have not entered the UK, the FDI net inflows would have been with 1.7 percentage points compared to the rest of the OECD countries that are not now in the EU. After the UK entrance in the EU, the mean difference between the EU members in the OECD and the rest of the OECD countries in terms of FDI as percent of GDP is about 3.7 percentage points. This means that EU countries from the OECD attracted with 3.7 percentage point more FDI as percent of GDP just because the EU membership over the period 1973-2014.

After the analysis of all of these cases, we can conclude that the UK entrance in the EU had significant positive effects on FDI net inflows compared to the other OECD countries, but if we make the comparison only with Norway and Iceland, OECD European countries that did not entered the EU, the UK did not significantly attract more FDI net inflows during 1973-2014. So, if the UK wants to maintain the ascending trend in FDI after Brexit, it should focus on the Nordic model of the nonEU countries.

\section{Conclusions}

The research hypothesis related to the negative effects of Brexit on FDI projects and inflows was validated and the main results indicated that the Brexit will negatively affect the number of FDI projects, but also the new and safeguarded jobs generated by these FDI projects. In this context, labour market will face many problems that should be prevented by suitable policy implementations. In this context, the recommendations should focus on the creation of a more flexible labour market to solve the issue of competitiveness loss. This research results are a novelty for the economic literature, because an impact evaluation refers to other variables related to FDI and the methods were not used before for this type of analysis. Even if severe problems are expected on the UK labor market, none of the previous studies took into consideration the 
assessment of Brexit impact on jobs related to FDI projects. The differences-in-differences approach is also a novelty for this topic, the comparison with OECD countries and non-EU states from Europe being necessary to propose the best policies for alleviate the high negative impact of Brexit on FDI. A concrete comparison with other studies cannot be made, because the other researches focused on bilateral flow, but the general tendency of negative impact of Brexit on FDI (presented by also by Campos \& Coricelli, 2015; Ebell \& Warren, 2016; Driffield \& Karoglou, 2016) is also validated in this study. The results are, actually, confirmed by the economists' expectation that support the benefits of economic integration.

Our results depend on the type of method. Other alternative methods on these data might provide slightly different results. In a future research, the bilateral FDI flows between the UK and different regions might be considered, because the Brexit effects do not resume to the UK. This event might bring risks and opportunities to the other countries within or outside of the EU.

\section{Appendix A. Supplementary material}

This article is dedicated to the Great Union Centenary. A preliminary version of the paper appears as discussion paper (not considered publication) in GLO Discussion Paper Series.

Supplementary data associated with this article can be found, in the online version, at https://dx.doi.org/10.14254/jems.2018.3-1.1.

\section{Citation information}

Simionescu, M. (2018). The impact of Brexit on the UK inwards FDI. Economics, Management and Sustainability, 3(1), 6-20. doi:10.14254/jems.2018.3-1.1.

\section{References}

Alfaro, L., Chanda, A., Kalemli-Ozcan, S., \& Sayek, S. (2004). FDI and economic growth: the role of local financial markets. Journal of International Economics, 64(1), 89-112.

Allison, P. D., \& Waterman, R. P. (2002). Fixed-effects negative binomial regression models. Sociological Methodology, 32(1), 247-265.

Barrell, R., \& Pain, N. (1997). Foreign direct investment, technological change, and economic growth within Europe. The Economic Journal, 107(445), 1770-1786.

Barrett, A. et al., (2015). Scoping the Possible Economic Implications of Brexit on Ireland. The Economic and Social Research Institute (ESRI), Research Series, No. 48, Dublin

Barrett, A., Bergin, A., FitzGerald, J., Lambert, D., McCoy, D., Morgenroth, E. \& Studnicka, Z. (2015). Scoping the possible economic implications of Brexit on Ireland. ESRI Research Series, 48.

Benito, G. R., \& Grünfeld, L. A. (2011). Inward FDI in Norway and its policy context. Retrieved from http://academiccommons.columbia.edu/catalog/ac:135214

Bertrand, M., Duflo, E., \& Mullainathan, S. (2002). How much should we trust differences-indifferences estimates? (No. w8841). National Bureau of Economic Research.

Bloom, N., Sadun, R., \& Van Reenen, J. (2012). Americans do IT better: US multinationals and the productivity miracle. The American Economic Review, 102(1), 167-201.

Bruno, R., Campos, N., Estrin, S., Tian, M. (2016). Gravitating towards Europe: An econometric analysis of the FDI effects of EU membership. CEP Technical Paper, Brexit Analysis No 3.

Campos, N. F., \& Coricelli, F. (2015). Some unpleasant Brexit econometrics. Retrieved 05.07.2016 from http://www.voxeu.org/article/some-unpleasant-brexit-econometrics

Crafts, N. (2016). The Growth Effects of EU Membership for the UK: a Review of the Evidence (No. 280). Competitive Advantage in the Global Economy (CAGE), Global Perspectives Series: Paper 7.

Dhingra, S., Ottaviano, G., Sampson, T., \& Van Reenen, J. (2016). The impact of Brexit on foreign investment in the UK. Centre for Economic Performance (CEP), London School of Economics and Political Science (LSE).

Driffield, N., \& Karoglou, M. (2016). Brexit and Foreign Investment in the UK. Available at SSRN 2775954. $\quad$ Retrieved $05.07 .2016 \quad$ from http://papers.ssrn.com/sol3/papers.cfm?abstract_id=2775954

Dunning, J. H. (1997). The European internal market programme and inbound foreign direct investment. JCMS: Journal of Common Market Studies, 35(2), 189-223.

Ebell, M., \& Warren, J. (2016). The long-term economic impact of leaving the EU. National Institute Economic Review, 236(1), 121-138.

El-Sayyad G. M. (1973). Bayesian and classical analysis of Poisson regression. Journal of the Royal Statistical Society, Series B: Methodological, 3, 445-451. 
Featherstone, K. (2016). External perspectives on the UK's membership of the European Union: report of the hearing held on 1st March, 2016. The London School of Economics and Political Science, European Institute, London, UK. Retrieved from http://eprints.lse.ac.uk/66954/

Gibbons, R. D., Segawa, E., Karabatsos, G., Amatya, A. K., Bhaumik, D. K., Brown, C. H., \& Mann, J. J. (2008). Mixed-effects Poisson regression analysis of adverse event reports: The relationship between antidepressants and suicide. Statistics in medicine, 27(11), 1814-1833.

Greene, William H. (2002). Econometric Analysis.New York, NY: Prentice Hall.

Harvey, D., \& Hubbard, C. (2016). Why Brexit?. Centre for Rural Economy Discussion Paper Series No. 35.

Haskel, J. E., Pereira, S. C., \& Slaughter, M. J. (2007). Does inward foreign direct investment boost the productivity of domestic firms?. The Review of Economics and Statistics, 89(3), 482-496.

Hsiao, C. (2003). Analysis of panel data, 2nd. Cambridge: Cambridge University Press.

http://citeseerx.ist.psu.edu/viewdoc/download?doi=10.1.1.38.7654\&rep=rep1\&type=pdf

http://www.cpb.nl/sites/default/files/publicaties/download/internal-market-and-dutcheconomy-implications-trade-and-economic-growth.pdf Retrieved 01.07.2016 from

Irwin, G. (2015). BREXIT: the Impact on the UK and the EU. Global Council, London. Retrieved from https://www.global-counsel.co.uk/sites/default/files/specialreports/downloads/Global\%20Counsel_Impact_of_Brexit.pdf

Kierzenkowski, R., Pain, N., Rusticelli, E., \& Zwart, S. (2016). The Economic Consequences of Brexit, OECD Economic Policy Papers, 16, 1-37.

Mansfield, I. (2014). A Blueprint for Britain: Openness not Isolation. Institute of Economic Affairs. London. $\quad$ Retrieved $\quad 01.07 .2016 \quad$ from http://www.iea.org.uk/sites/default/files/publications/files/Brexit\%20Entry\%20170_final _bio_web.pdf

McGrath, P. (2016). Brexit and Likely Implications for Ireland. Retrieved from http://papers.ssrn.com/sol3/papers.cfm?abstract_id=2758850

Meyer, B. (1995). Natural and Quasi-Natural Experiments in Economics. Journal of Business and Economic Statistics, XII, 151-162.

Pain, N., \& Pickering, J. F. (1996). Continental drift: European integration and the location of UK foreign direct investment (No. 107). National Institute of Economic and Social Research.

Pain, N., \& Young, G. (2004). The macroeconomic impact of UK withdrawal from the EU. Economic Modeling, 21(3), 387-408.

Purdue, D., \& Huang, H. (2015). Brexit and its Impact on the Irish Economy. National Treasury Management Agency, Dublin. Retrieved from www.ntma.ie/download/BrexitIrish\%20Economy.pdf

PWC. (2016). Leaving the EU: Implications for the UK Economy. Retrieved from http://www.pwc.co.uk/economic-services/assets/leaving-the-eu-implications-fortheukeconomy.pdf).

Ramasamy, B. \& Yeung, M. (2010). The determinants of foreign direct investment in services. The World Economy, 33(4), 573-596.

Straathof, B., Linders, G. J., Lejour, A., \& Jan, M. A. (2008). The Internal Market and the Dutch economy: Implications for trade and economic growth (No. 168). CPB Netherlands Bureau for Economic Policy Analysis. The Hague.

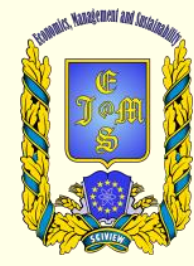

(c) 2016-2018, Economics, Management and Sustainability. All rights reserved.

This open access article is distributed under a Creative Commons Attribution (CC-BY) 4.0 license.

You are free to:

Share - copy and redistribute the material in any medium or format Adapt - remix, transform, and build upon the material for any

purpose, even commercially.

The licensor cannot revoke these freedoms as long as you follow the license terms.

Under the following terms:

Attribution - You must give appropriate credit, provide a link to the license, and indicate if changes were made.

You may do so in any reasonable manner, but not in any way that suggests the licensor endorses you or your use.

No additional restrictions

You may not apply legal terms or technological measures that legally restrict others from doing anything the license permits.

Economics, Management and Sustainability (ISSN: 2520-6303) is published by Scientific Publishing House "CSR",

Poland, EU and Scientific Publishing House "SciView", Poland

Publishing with JEMS ensures:

- Immediate, universal access to your article on publication

- High visibility and discoverability via the JEMS website

- Rapid publication

- Guaranteed legacy preservation of your article

- Guaranteed legacy preservation of your article

Submit your manuscript to a JEMS at https://jems.sciview.net or submit.jems@sciview.net 